\title{
The materiality of things? Bruno Latour, Charles Péguy and the history of science
}

History of the Human Sciences 26(I) 3-28

(C) The Author(s) 2012

Reprints and permission: sagepub.co.uk/journalsPermissions.nav DOI: $10.1177 / 0952695$ I I 2461736 hhs.sagepub.com @SAGE

\author{
Henning Schmidgen \\ Universität Regensburg, Germany
}

\begin{abstract}
This article sheds new light on Bruno Latour's sociology of science and technology by looking at his early study of the French writer, philosopher and editor Charles Péguy (1873-1914). In the early 1970s, Latour engaged in a comparative study of Péguy's Clio and the four gospels of the New Testament. His 1973 contribution to a Péguy colloquium (published in 1977) offers rich insights into his interest in questions of time, history, tradition and translation. Inspired by Gilles Deleuze's philosophy of difference, Latour reads Clio as spelling out and illustrating the following argument: 'Repetition is a machine to produce differences with identity'. However, in contrast to Deleuze's work (together with Félix Guattari) on the materiality of machines, or assemblages [agencements], Latour emphasizes the semiotic aspects of the repetition/difference process. As in Péguy, the main model for this process is the Roman Catholic tradition of religious events. The article argues that it is this reading of Péguy and Latour's early interest in biblical exegesis that inspired much of Latour's later work. In Laboratory Life (Latour and Woolgar, 1979) and The Pasteurization of France (1988) in particular, problems of exegesis and tradition provide important stimuli for the analysis of scientific texts. In this context, Latour gradually transforms the question of tradition into the problem of reference. In a first step, he shifts the event that is transmitted and translated from the temporal dimension (i.e. the past) to the spatial (i.e. from one part of the laboratory to another). It is only in a second step that Latour resituates scientific events in time. As facts they are 'constructed' but nevertheless 'irreducible'. They result, according to Latour, from the tradition of the future. As a consequence, the Latourian approach to
\end{abstract}

\section{Corresponding author:}

Henning Schmidgen, Institut für Information und Medien, Sprache und Kultur (I: IMSK), Universität Regensburg, Universitätsstrasse 31, 93053 Regensburg, Germany.

Email: henning.schmidgen@ur.de 
science distances itself from the materialism of Deleuze and other innovative theoreticians.

\section{Keywords}

actor network theory, biblical exegesis, history of sociology, Bruno Latour, Charles Péguy, materialism, tradition

Deleuze is the greatest French philosopher (along with Serres). ... I have read Deleuze very carefully and have been more influenced by his work than by Foucault or Lyotard. (Bruno Latour, in Crawford and Latour, 1993: 263)

[L]e catholique est un garçon qui arrive sur la route et qui trouve très bon pour lui le poteau indicateur qu'il y a pour tout le monde. (Péguy, 1961a: 1551-2)

\section{Introduction}

Bruno Latour is not a historian of science. Despite this, historians of science have responded intensively to his writings. Because Latour describes the world of science as a 'seamless web' that no longer admits any external point of view (Shapin, 1988: 547), because he dispenses with causal historical and/or sociological 'explanations' for the actions of scientists in concrete situations (Golinski, 1990: 500), because of his 'hylozoism' which relativizes the difference between human and non-human actors (Schaffer, 1991: 182), and, more generally, because of his relapse into 'oldstyle realism' (Lenoir, 1994: 126) or 'naive, preKantian empiricism' (Sarasin, 2003: 203) trained historians of science have criticized his approach as problematic and potentially misleading (Zammito, 2004: 183-205). ${ }^{1}$

At the same time Latour's work has been credited with exerting a 'lasting influence' on historical studies of experimental practices (Golinski, 1990: 496), in particular with his pioneering book Laboratory Life, co-authored with Steve Woolgar in 1979. Some historians of science claim that Latour's writings 'offer many conceptual resources that can be productively applied to historical research' (ibid.: 500). In particular, Peter Galison (1997: 15) and Hans-Jörg Rheinberger (1997: 3-4) have referred to and relied on Latour when exploring the heterogeneity of scientific practice and when writing the history of science as a 'history of things' (Latour, 1996; 1999: 145-73).

Throughout many of his studies Latour himself refers to historians of science - to classic authors, such as Gaston Bachelard, Alexandre Koyré and Thomas Kuhn, and contemporary representatives of the field, for example, Robert Fox, Gerald Geison, Thomas Hughes and Daniel Kevles. As a rule, Latour does not challenge these more recent authors using them as a basis for sociological and historical arguments about science and technology, but his verdict on traditional history of science is almost exclusively critical (see, for example, Bowker and Latour, 1987).

In We Have Never Been Modern Latour explicitly distances himself from history of science. As is well known, the book derives its notion of the 'modern constitution' from 
an intense engagement with Steven Shapin and Simon Schaffer's Leviathan and the AirPump. However, Latour plays down the role of history in this context, claiming: 'I have none of the historical skills of my colleagues [i.e. Shapin and Schaffer] and I will have to rely on what is, of necessity, a speculative exercise' (Latour, 1993a: 30). In other words, Latour does not aim to develop a historical argument about epochs and their time-spans. Rather, We Have Never Been Modern creates a thesis whose validity has yet to be proved through historical research. Perhaps this is why Latour does not dispel the impression that 'the modern constitution' is a question of mindsets, interpretations and ways of thinking - hence of the 'psycho-social profile' (Latour, 1999: 277), as he expresses it elsewhere.

There is an obvious reason for Latour's caution concerning history - he is a philosopher by training. From 1966 to 1972 Latour pursued his studies in philosophy at the University of Dijon. His most important teacher at this institution was the former Roman Catholic priest André Malet. After having converted to Protestantism in the late 1950s, Malet became especially interested in the work of the German theologian Rudolf Bultmann (Malet, 1962, 1968), famous for his innovative form of biblical exegesis and his extensive dialogue with Martin Heidegger. Between 1923 and 1927, Bultmann and Heidegger taught at Marburg University and were in almost constant dialogue. During this time, both started to argue against the far-reaching claims of scientific objectivity. Opposing the then dominant school of Neo-Kantianism, Bultmann and Heidegger contrasted science with religion, art and technology as autonomous forms of existence that, in their eyes, were, at the same time, autonomous forms of truthful interpretation, or Auslegung (Bultmann and Heidegger, 2009; Bormuth and von Bülow, 2008; on Latour and Heidegger see Riis, 2008; Harman, 2009; Kochan, 2010; Erdély, 2011).

Latour spent four years with Malet and studied Bultmann's work intensively during that period. As he recently confirmed in an autobiographical note, it was his reading of Bultmann that primed him to detect the 'exegetic dimension in the immense complexity of scientific practice' (Latour, 2010: 601). However, up until today Latour has not spelled out the theoretical and historiographical implications of this biographical feature. This is the task of the present article. ${ }^{2}$

\section{Time matters}

In 1975, Latour graduated from the University of Tours with a thèse de troisième cycle entitled 'Exegèse et ontologie à propos de la resurrection' [Exegesis and Ontology with Respect to the Resurrection]. This unpublished work was supervised by Claude Bruaire, who is widely considered a 'theological philosopher' and a 'Christian rationalist' (Kühn, 1993; see also Roßler and Latour, 1997: 45). In the same context and the same period, Latour's first publication appeared, a lecture held in 1973 and published in 1977 on the problem of repetition in the work of the philosopher, writer and editor Charles Péguy. This lecture focuses on one of Péguy's most famous works, Clio: Dialogue de l'histoire et de l'âme païnne [Clio: Dialogue between History and the Pagan Soul]. Published posthumously in excerpts in 1917 and 1918, Clio appeared for the first time in its entirety in 1932, followed, in 1955, by an earlier, alternative version, which is entitled Véronique: Dialogue de l'histoire et de l'âme charnelle [Veronica: Dialogue between 
History and the Earthly Soul] (see Péguy, 1961b and 1961c). Latour engaged with both versions of this dialogue and offered a structuralist reading of them, making a comparison with the textual structure of the New Testament gospels.

Taking into account Latour's philosophical interest in theology and his early study of Péguy allows for an approach to his work that does not reiterate the labels which, in the meantime, seem to be well established. In what follows, Latour is not primarily portrayed as a science and technology scholar, a sociologist/anthropologist of scientific practice and everyday technology, or a political scientist and 'parliamentarian' of things. Instead, he is presented as a philosopher for whom the relationship between experience, time and history is a central theme, specifically in the form of tradition.

From a sociological point of view Helga Nowotny (1994: 79) and Andrew Pickering (1995: 3) have raised the objection that Latour's approach leads to an extremely spatialized and static view of science, which in no way does justice to the internal and external dynamics of scientific processes. The present article suggests that the spatialized portrayal of laboratory practice in Laboratory Life can be understood as a paradoxical but certainly interesting result of a far-reaching engagement with the problem complex of experience, time and history.

More concretely it will be shown that in Latour's writings the tradition-space of the laboratory arises through a 'rotation' of the tradition-time of history. In his early work, Latour's notion of tradition moves from the horizontal to the vertical so that the problem of (historical) tradition becomes a problem of (contemporary) communication and translation. In his later writings he performs a further rotation from the vertical to the horizontal where that which is generally considered as 'future' becomes that which is handed down, i.e. transmitted. As a consequence, the laboratory becomes a non-modern space of knowledge that is characterized by a specific kind of tradition, i.e. the tradition of the future.

Tracing these turns, the article also shows that the problem of 'experience, time and history' in Latour's work is placed and repeatedly discussed in a theological register. In line with his early interest in Malet and Bultmann, Latour primarily understands himself as an 'exegete' of scientific documents (texts, images). In fact, the discipline with which he explicitly connects, when reconsidering his academic career, is neither sociology nor anthropology but biblical exegesis (more generally on this point, see Golinski, 2010).

Latour frequently refers to his roots in this field: 'I was trained in philosophy and biblical exegesis', he states, for example, in an interview with Hugh Crawford (Crawford and Latour, 1993: 250), and in Laboratory Life Bultmann's 'history of form' [Formgeschichte] is mentioned in connection with the interpretation and contextualization of scientific 'stories'. Further, on the first pages of The Pasteurization of France Latour refers to the discussion of biblical exegesis in Spinoza's Theologico-Political Treatise to characterize his own method of dealing with sources from the history of science (on Spinoza and biblical exegesis, see also Malet, 1966).

From today's standpoint, this convergence between theology and science studies might seem surprising. However, since its beginnings the sociology of science paid attention to the problem of religion. This holds true for Émile Durkheim's (2008[1912]) pioneering study of the fundamental notions of thought, or categories, in The Elementary Forms of Religious Life as well as for Max Scheler's (1924) programme 
for a cultural 'Sociology of Knowledge' aiming to investigate the factual statements of the natural sciences as well as the specific kinds of knowledge created by religion and philosophy.

Moreover, concrete examples for the connection between theology and the sociology of science can be found in the French context of the late 1960s. Most importantly, the Jesuit historian, sociologist and philosopher Michel de Certeau investigates, in a series of essays, 'what contemporary societies make out of religion' (de Certeau, 1971: 1178). Science was one of the examples de Certeau referred to in this context. In the heyday of structuralism, he questioned the importance of the hard sciences for understanding the totality of human reality. In the wake of Michel Foucault, de Certeau referred to language and history as the 'unspoken' [non-dit] of the sciences and highlighted the fact that the functioning of science is always tied to 'the facticity of its dependencies and the contingency of practice' (ibid.: 1191, 1197). More generally, he stated: 'There is an essential relation between the universality that any authentic science strives for and the specificity of its socio-historical situatedness' (ibid.: 1197).

Early on, one of de Certeau's students, the theologian and former micro-physicist Georges Thill, developed these observations into what he called a 'praxeology of science' (Thill, 1973). A key element of this praxeology was a 'laboratory diary' that Thill kept while working in various research institutes for particle physics. As de Certeau's biographer François Dosse (2002: 367) has suggested, this diary and its extended theological, sociological, cultural and existential analyses concerning the 'functioning of scientific production' (Thill, 1973: 21) can be seen as one of the models for Latourian laboratory studies.

Despite the fact that Latour rarely refers to de Certeau (see, however, Latour and Woolgar, 1979: 107), his interest in observing laboratory science 'in action' inscribes itself into this contemporary convergence between theology and the sociology of science. As the present article argues in particular, Latour's parallel exegesis of Clio and the New Testament gospels played a decisive role in the fact that his sociological attention to science focused, from the start, on the issue of inscription and translation.

To date there is only one book in which Latour (2002a) explicitly engages with the question of religion and religiosity: Jubiler - ou les tourments de la parole religieuse [Jubilate - or, the Torments of Religious Speech]. Yet the importance of Latour's parallel look at 'old religion' and 'new science' can be construed from the programmatic concluding section of his book La clef de Berlin [The Berlin Key]:

There is transcendence in science just as there is transcendence in religion; reference exists in religion just as it exists in scientific work; there is scientific re-presentation just as there is religious re-presentation. There is transcendence in abundance. What is lacking is belief, whether of a religious or, as is more common today, a scientific variety. (Latour, 1993b: 252)

It is not melancholy that speaks out of these sentences. Rather, it is the comparatively sober observation of a 'lover' [amateur] of science who is obviously also a lover of religion.

The present article will not enter into a discussion of Latour's recent arguments concerning a distinction between representational practices in sciences and religion (see 
Latour, 2002a, 2005). Instead, it aims at clarifying why Latour's early work on science focused on representational practices, despite the fact it repeatedly refers to a 'history of things'. In this respect, Latour's continuing reference to Péguy's Clio is highly interesting. As it turns out, Latour's early study of Péguy was by no means a finite episode. Twenty years later, he still refers to Péguy as 'the greatest French prose writer and no doubt the deepest philosopher of time' (Latour, 1997: 179). There is also no lack of references to Clio in Latour's other works. In The Pasteurization of France he characterizes this dialogue as 'probably the most profound study on the articulations of the various historical and religious times' (Latour, 1988: 258) and We Have Never Been Modern cites Clio as 'a stunning meditation on the brewing of history' (Latour, 1993a: 68).

For the present article, this enduring orientation toward Péguy is just as important as the fact that Clio mediates an encounter of Latour and Gilles Deleuze. Although Latour makes frequent reference to Michel Serres and his writings (on Serres, see Shortland, 1998), he has never left any doubt about how important the philosophy of Deleuze is for his own work - even though he cites the works of Deleuze relatively sporadically. ${ }^{3}$ In fact, the connection between difference and repetition, between event and history, is central for Latour just as it is for Deleuze. Despite this fact, however, Latour engages only cautiously with the materialist philosophy of machines and assemblages [agencements], which Deleuze developed in cooperation with Félix Guattari, relying in multiple ways on Marxist theory (Holland, 1999).

Similar to the factory (one of Deleuze and Guattari's favourite examples) a biological laboratory can be viewed as an emblematic space for the 'machinization', the temporary 'connection' and 'disjunction' of natural and artificial 'partial objects' derived from humans and machines. But even in Laboratory Life Latour focuses on issues of inscription and interpretation; for him (and his co-author Woolgar) it is the desk that forms the centre of all laboratory activities, not the machines. Accordingly, the 'things' whose history Latour demands are by no means as tangible as those of other historians and/or sociologists. For example, there is an obvious contrast between Latour's history of things and Walter Benjamin's notion of a materialist history that would be guided 'by the objects themselves' (Benjamin, 2002: 283; for a rather polemic statement by Latour on Benjamin, see Hennion and Latour, 2003).

In Latour, the things of science retain a lightness and transcendence, which eventually cannot be referred back to material, economical and/or social configurations. It is rather obvious, then, that with Latour the history of science is not getting back its materialism (for an anticipated ironic response to this, see Latour, 2007).

\section{Who was Péguy?}

Charles Péguy was a philosopher, writer and editor. He wrote essays, polemics, dialogues, stage plays and religious epic poems. Péguy was also the founder, editor and publisher of the journal Cahiers de la Quinzaine, in which from 1900 to 1914 contributions by authors such as Henri Bergson, Anatole France, Jean Jaurès and Romain Rolland appeared as well as Péguy's own texts, among them some polemical statements directed against the 'Sorbonne sociology' as represented by Émile Durkheim (for a Péguy biography in English, see Villiers, 1965). 
Introducing Péguy's work to a German-speaking readership for the first time in 1919, literary critic Ernst Robert Curtius wrote 'that no other French writer has succeeded in conveying such deep insights into the political and intellectual history of France since the Dreyfus Affair; that the defining problem of his [Péguy's] thought is the relationship of reality and history; that he combats the modern Zeitgeist with the powers of the heroic and the religious' (Curtius, 1919: 195).

In the same year Walter Benjamin wrote in a letter to his friend Gershom Scholem:

I have again read some things by Péguy. In this instance, I feel that I am being addressed by an unbelievably kindred spirit. Might I be permitted to say that nothing written has ever impressed me so very much because of how close it is to me, because of my feeling of oneness with it. Of course a lot of things have shaken me more; this touches me, not because of its sublimity, but because of its kinship to me. (Benjamin, 1994: 147; original emphasis)

Shortly before, Benjamin had read excerpts from Péguy's posthumously published work 'Nota conjuncta' in the Nouvelle Revue Française in which Péguy defends his academic teacher Bergson whose works were about to be put on the Index by the Roman Catholic Church.

It is not certain whether Benjamin also knew Péguy's Clio. As mentioned above, extracts from this 'Dialogue between History and the Pagan Soul' were first published posthumously in 1917 and 1918 in the journal La Grande Revue, and the complete text appeared for the first time in 1932. In this period Benjamin only mentions Péguy sporadically. As Benjamin expert Hella Tiedemann-Bartels surmises in her study Verwaltete Tradition: Die Kritik Charles Péguys [Administrated Tradition: The Criticism of Charles Péguy], at this point in time the author of 'The Work of Art in the Age of Mechanical Reproduction' and 'Theses on the Philosophy of History' seems to have "forgotten the "closeness" to and the "kinship" with Péguy, or wanted to forget it’ (Tiedemann-Bartels, 1986: 281).

Nevertheless, according to Tiedemann-Bartels there is an affinity between the two writers; not outwardly, for example, at the level of writing style (at an early stage Leo Spitzer and other linguists were most interested in Péguy's style, which at once 'forges ahead' and 'stutters' [Spitzer, 1928: 320, 332]), but an affinity that exists in their motivation, their orientation. As Tiedemann-Bartels (1986: 282) writes: 'Benjamin's concepts of the cult and exhibition value of art as well as his critique of the philosophy of history are reminiscent of Péguy's motifs'.

As a first step Clio can be understood as the result of transposing Bergson's philosophy of time onto the problem of history under the auspices of a gradual turn to Roman Catholicism. Similarly to how Bergson contrasts time and duration, intellect and intuition, Péguy differentiates between history and tradition, science and experience. To illustrate this difference, in Clio, for example, historical accounts are compared with a long railway line that runs along the coastline at a certain distance from it which allows one to stop at any station one wishes; tradition, the collective memory, in this metaphor is the coast itself, with its marshes, people, fishes, estuaries of rivers and streams, the life on land and the life on the sea (see Péguy, 1961b: 286).

Clio develops this ambivalent metaphor in the context of a critique of modernity and the importance it accords to scholarly engagement with history. That research methods 
and instruments take priority in the way the discipline of history is organized is for Péguy one of the greatest errors of modern times. As he writes in a different work: 'As though ignorance of the present were an essential condition for attaining access to knowledge of the past' (Péguy, 1959: 997).

Péguy's counter-concept of history to that of the Sorbonnards is oriented on secondary school teachers in rural areas, who act on the basis of their 'incommunicable experience' as (family) people and (world) citizens; that is, as committed witnesses to history in a precarious social situation, to achieve orientation about history and to orient themselves on history. In contradistinction to the methods of professional historians, which are imbued with a belief in progress and therefore only ostensibly neutral, Clio relies on the ethos of memory, preservation and bringing to mind. With concepts such as rendre, entendre, interpréter and représenter Péguy designates a method of remembering and recounting 'that serves memory of the bygone world, which is handed down' (Tiedemann-Bartels, 1986: 226).

Péguy assumes that the most important example for and model of this kind of handeddown memory is the language of signs, forms and figures in which the Christian God addresses humans. The fullest expression of this language for Péguy is the fact of the incarnation, i.e. the birth of Jesus. Accordingly, the muse of modern historiography seems highly problematic for she merely appears as the 'young lady of the records'. The author of Clio can see in her only a pillar saint of a religion of 'stamped sheets of paper': 'Always this superstition, this cult of the inscription. Always this idea that inscription leads to the action, is the action' (Péguy, 1961b: 210, 213).

In another text Péguy confronts this cult with a more authentic world of incarnation and inscription. Alluding to church buildings Péguy brings together script and body, prayer and stone:

Works that do not detach themselves one iota from the cult and prayer and worship; so little that they are like, they are literally a physical inscription, a temporal inscription, an inscription carved in stone, stone, taking place in stone, of the service and prayer, the innermost, and of the most fervent worship. The worshipped body, works of stone, inscriptions, incorporations. (Péguy, 1961d: 951)

Here inscriptions are not merely a matter of pen and paper; rather, they are embedded in a space in which there are encounters between people and things. Thus they are not a silent and flat archive, but part of a ritual that is both physical and meaningful.

\section{Differences and repetitions}

Gilles Deleuze has pointed out that Péguy's philosophy of history is associated with a specific conception of repetition and event. In Difference and Repetition, Deleuze (1994[1968]) compares Péguy to Kierkegaard for whom repetition was also disconnected from the notion of going back to the past in a self-similar way and redefined as a forward-looking, open-ended process, which 'recollects forward', as Kierkegaard (1983[1843]: 131) himself puts it. As Deleuze further explains, Péguy does not understand tradition from a particular end-point of a series of events (as the 'railroad' 
historians), he proceeds from the unique event that is the reason for the process of passing something on in the first place, sets the process in motion and continues it.

To illustrate this thesis Deleuze cites two passages from Clio. The first concerns Claude Monet's paintings of water lilies, Nymphéas. Péguy has his muse of history say about this series of paintings:

... which of these twenty-seven and of these thirty-five water lilies is painted the best? The most logical impulse would be to say: The last one, because he was able to do it the best. And I say: On the contrary, actually the first, because he was able to do it least well. (Péguy, 1961b: 126)

Here, repetition is defined as a relationship to and an attitude toward an event that is not similar or equivalent to anything else. As Deleuze puts it, repetition 'interiorizes and thereby reverses itself" (Deleuze, 1994[1968]: 1). The singularity of the first painting of water lilies triggers a creative process in Monet that is both repetitive and differentiating; it leads to further paintings of water lilies and it is ongoing. As a unique happening it remembers itself 'recollecting forwardly', to paraphrase Kierkegaard, in all subsequent paintings.

That Péguy also argues in this manner with regard to historical events is illustrated by Deleuze's second example from Clio: Péguy suggests that the storming of the Bastille cannot be attributed to the logic of history, external reasons, or motives, but it was due to a kind of mood of the people, their basic spontaneity:

The Bastille had never done anything to them. The storming of the Bastille ... was actually a festival, it was the first celebration, the first commemorative ceremony and the first anniversary, so to speak, of the storming of the Bastille. (Péguy, 1961b: 180)

Just as Monet's first painting of water lilies brought forth all the others that followed, it is the historical event itself, as Deleuze says, 'which celebrates and repeats in advance all other Federation days' (Deleuze, 1994[1968]: 1).

In Difference and Repetition Deleuze puts Péguy alongside Kierkegaard and Nietzsche as a 'triptych of priest, Antichrist, and Catholic', which stands at the beginning of his endeavour to make repetition the fundamental category of a new philosophy (1994[1968]: 5). Yet it was not only Péguy's theory of the (historical) event that made him one of the 'great repeaters of history' (ibid.: 22) for Deleuze. Péguy had also contributed to developing a new means of expression, a new praxis of writing with which 'to put metaphysics in motion, in action' (ibid.: 8).

What Deleuze is referring to is on the one hand the theatrical, the dialogic aspect of Péguy's works, and on the other his style, which has been analysed by Spitzer and others, and characterized as at once flowing and interrupted. According to Deleuze Péguy employs series of synonyms and contiguities with which he generates small differences of meaning to open up the 'internal space' of the words (1994[1968]: 22). Thus for Péguy repetition is not only a theme, it also shows up performatively.

Indeed, Deleuze goes so far as to suggest that it is even possible to detect at the level of Péguy's writing style the differentiation that is postulated in Clio between the 
railroad-type time of history and science on the one side, and the planar seashore-time of tradition and experience. Deleuze writes in The Logic of Sense:

Péguy was able as well to invent an entire language, among the most pathological and aesthetic that one might dream of, in order to explain how a singularity is prolonged in a line of ordinary points, but also how it begins again in another singularity, how it redistributes itself in another set. (Deleuze, 1990[1969]: 53)

It is this observation - which Deleuze does not elaborate on - that marks the point at which Latour's exploration of Péguy's work begins.

\section{Latour, Clio and the New Testament}

As the title of Latour's first paper shows, his central questions are: 'Why does Péguy repeat himself? Is Péguy unreadable?' To find answers he assumes, like Deleuze, that there exists a close connection between Péguy's repetitive style and his conception of time and history. In Latour's opinion Clio is particularly interesting in this respect because this dialogue engages both content-wise and formally with the problem of temporality:

In this work temporality personified (Clio) speaks about temporality and a great many other things, which do not appear to be connected except by the association of words, but are connected nonetheless because she [Clio] applies the methods of which she speaks. Through an incredible concentration the structure, the theme and the style thus coincide to reveal the machinery of time. (Latour, 1977: 81; original emphases)

If this intricate and also instructive coinciding of different (time) levels is responsible for the fact that Latour orients his study of 'the real meaning of Péguy's style' exclusively on Clio, it is at the same time the reason why he does not analyse Péguy's style in detail. Latour assumes that Péguy's style has a non-stylistic basis. Consequently, he chooses consciously to attempt a 'non-literary' analysis that distances itself quasiethnologically from Clio (1977: 77).

Latour approaches the text via the reader, and not via the actual text. On readers, Péguy's repetitions - 'these unceasing digressions, these monstrous paragraphs, these violent accelerations' (1977: 79) - would exert a specific, precisely calculated effect; namely, suspension of all the usual criteria of readability. In this sense Péguy is indeed unreadable, for the underlying goal of this writer is to dissuade readers from pursuing their usual habits of reading, comprehending, thinking, and even living. Expressed in general terms: 'Repetition is the engine of war invented by Péguy to combat the refrain [ritournelle] and the saying of the same [rabachage]' (ibid.: 80). And put concretely: Clio is first of all a 'manual for reading correctly'. Against the established habits of an entertaining, historical and/or clerical reading, this dialogue offers a way of reading that 'breaks with old habits', that allows the originality of a text to appear once again. True reading persuades a text to start over again, and makes it into an event, which comes to the reader in the present moment from far away. 
According to Latour, one of the characteristics of this kind of reading is a change in the usual direction of reading. Reading does not any more proceed horizontally, but takes place, turned by 90 degrees, vertically. It is no longer about the superficial sequence of words in lines, nor is it about the lateral connection of one text to others; rather, it is a connecting of what has been read back to the depths of time, the recourse of present reading to the past event of the book. Péguy's distinction between history and tradition, science and experience, is found here at the level of the reader and the reader's willingness, or rather responsibility, to read an old text in a genuinely new way.

In a second step Latour undertakes a vertical reading of Clio - literally. In the course of this the quasi-ethnological distance to the text changes into an actual ethnological distance. For in this section of his study Latour follows a method developed by Claude Lévi-Strauss (1970-81) to examine myths in which text units are arranged in a table and subdivided with respect to their 'rhythm' and 'tonality'. Aided by this 'text raster' Latour claims to be able to infer the 'precise logic' of Clio I and Clio II.

For the first Clio version he presents this logic in a schematic diagram (Fig. 1), which summarizes the various aspects of Péguy's philosophy of time and history. In the bottom half of the diagram one can clearly see the difference between the linear, 'extensive' (railroad) time of history and the wider distribution of the 'intensive' (seashore) time of tradition, as well as that both are bound to the moment, the present, which for its part does not remain purely a time-determined entity, but is based on being. (In this connection Latour emphasizes that Péguy was a student of Bergson's, for whom the flow of time coincides with the flow of being.)

Like Latour's table by means of which he structures and subdivides the text of Clio, this diagram facilitates a calculated distance from the literary text, which according to Latour is an important feature of any 'correct exegesis'. Latour proceeds on the assumption that for a Péguy text a commentary is only apposite if it does not use any of the words in the text, 'because then it would record again the enigmatic text in an ordinary sense' (Latour, 1977: 85; original emphases).

No reproduction, no citation - just differentiating repetition in Péguy's sense of the term. The distance that had been attained previously changes quietly into closeness, into kinship, similar to Benjamin's experience with Péguy.

The third section of Latour's reading of Clio focuses on Péguy's Roman Catholicism. Here, Latour points out that Péguy was not only a student of Bergson's who equalled being and time, he was also a disciple of John the Evangelist 'for whom the word became flesh' (1977: 20). According to Latour, this becomes quite clear in the version of Clio published in 1955. Whereas Clio I is primarily devoted to elaborating history and tradition as opposites, after undertaking a further vertical reading of the texts, Latour says that Clio II develops a more complex, dialectical opposition: on one side are the opposites temporal and eternal, and on the other the unity of eternal and temporal. The relations that result Latour represents as a matrix of oppositions in which Péguy characters such as 'the historian', 'the cleric' and 'Jesus' meet (historian and cleric against Jesus, historian against cleric, etc.).

In this context, 'Jesus' does not only stand for the historical person, nor even (just) the Christ figure. The name stands for what Péguy regards as the ultimate event, through which the language of God becomes incarnated, incorporated and finally also inscribed: 


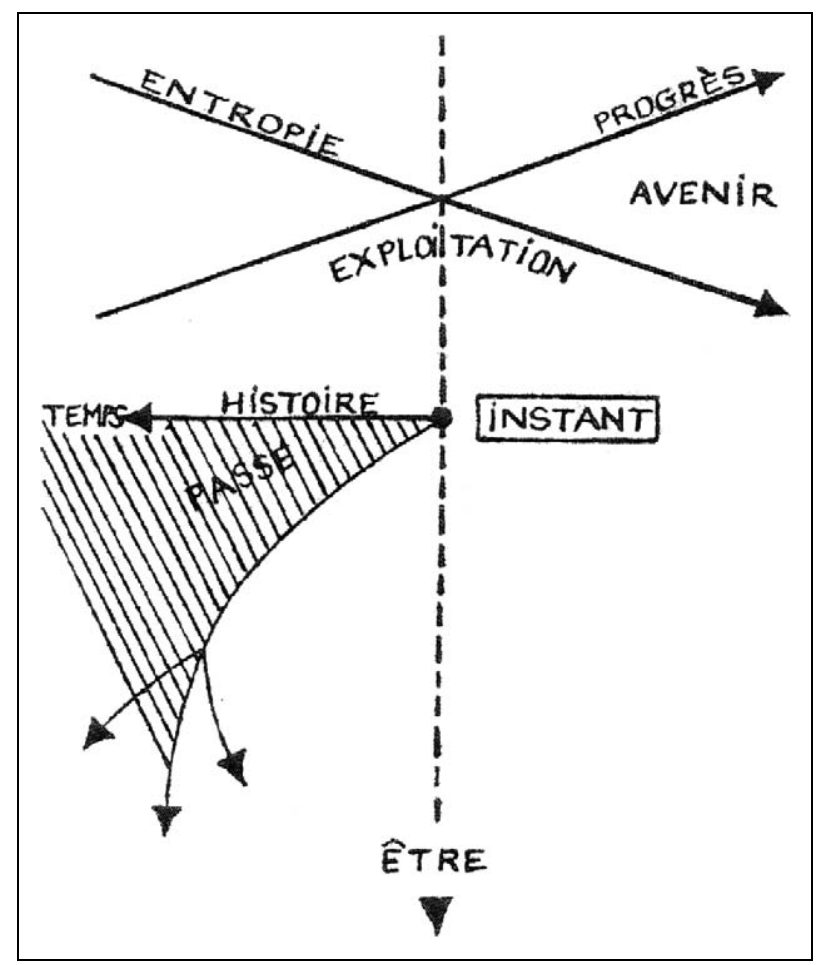

Figure I. Latour's diagram of Péguy's philosophy of time. In the top half the time of progress (the time of money, of capital) crosses the time of entropy (the everyday time of people). They come together in the movement of exploitation. For an explanation of the lower half of the diagram, see text.

(Figure reproduced from Latour, 1977: 85)

the birth of Jesus. At the same time Péguy also takes this name, as Latour explains, to describe the essential structure of time: "He [Péguy] calls "Jesus" the true operation of time and also the process of dissuasion as well as the irresistible opening up of history' (1977: 95).

This would appear to indicate that Péguy's Roman Catholicism, to which reference has often been made, does not so much depend on his use of religious concepts, but primarily on a way of writing, a style. Péguy does not (or does not only) adapt, popularize, or modify the contents of the Roman Catholic religion; rather, he allows them to begin anew as such: 'By means of Péguy's repetition each person hears the word of God in their own language; repetition renews the work of Whitsun' (1977: 93; original emphases).

Therefore, Péguy is not a representative or prophet of Roman Catholic religion; for Latour he is nothing less than a new evangelist, i.e. the author of an additional gospel. Péguy's repetition repeats the repetition of the four gospels: 'He [Péguy] is really the one who once again and using the same method brings the Glad Tidings of past breaking of habits, the Glad Tidings of past events, of the perennial openness of the event' (1977: 94). 
In Latour's eyes a vertical reading of the four gospels after the manner of Lévi-Strauss would actually show that these have the same internal structure, the same rhythm as Clio. In this way the gospels and their tradition are relocated within the horizon of reflection that Péguy spans in the Clio dialogue: 'the great and constant movement of exegeses, rereadings and revision of the Holy Scriptures belong precisely to the machinery which Clio has made its subject' (1977: 93).

At this point it is evident how far Latour has diverged from Deleuze. The distance between the two not only results because Deleuze's remarks on Péguy focus mainly on Clio I, and Latour offers a detailed analysis of both Clio I and II. Deleuze relates repetition as a theme and as a style in Péguy's work to a general theory of the 'recollected forward' event, whereas Latour relates it to a specific event in the Roman Catholic religion and the concrete form of how it has been transmitted through the Bible.

Deleuze sees Clio I as a 'culmination of Kant', because Péguy delegates the problem of overcoming the death of God and of the wound that this opens up in the self to faith (Deleuze, 1994[1968]: 95). Latour, on the other hand, constructs with Péguy an entire ontology of the event, which is realized and extrapolated through exegesis, rereadings and revisions. What begins as reflections upon time and history culminates in equating being a good Christian with being a good reader and a good contemporary (see Latour, 1977: 95).

Were it not for its Roman Catholic tone this equation would be very reminiscent of Walter Benjamin. As is well known, in Benjamin it is the figure of the solitary collector who combines a conspicuous understanding and exegesis of texts with an interest in the history of things: in this way the collector becomes a materialist historian because he allows himself to be led by 'the objects themselves'. In Latour, by contrast, the possibility of writing a history of things derives from understanding the things in a 'non-reductionist' way, in which these appear to be pre-eminently events of a certain form of exegesis. Or at least this applies, as will be demonstrated now, to the sphere of scientific objects.

\section{Rotating the problem of tradition}

'Repetition is a machine to produce differences with identity' (Latour, 1977: 99). Although this sentence of Latour's sounds Deleuzian, the 'machineries' with which he engages after his study of Péguy can hardly be compared with the heterogeneous production assemblages that Deleuze described and explored in his collaboration with Félix Guattari. For Latour the body as an 'overheated factory' under the skin is not of prime interest, or the industrial subjection of 'mechanical and intellectual organs' to the central motive force of a factory, or the seemingly crazy concatenations a' la Beckett in which 'a shoe, a pipe bowl, a small limp bundle that is undefined, a cover for a bicycle bell, half a crutch' can be persuaded temporarily to function in concert - also and especially when this succeeds only with breakdowns, noises and interruptions (Deleuze and Guattari, 1983[1972]: 3, 324; 1977: 131). Latour is interested in the particular machineries that pass things on, which, via paper and writing, inscribed surfaces and registration devices, allow one to connect to events that cannot be grasped, or only imperfectly, with a modern and/or secularized conception of history. 
Laboratory Life illustrates the fact that the comparatively mundane sphere of machines is not placed in the centre of the analyses provided by Latour and his coauthor Steve Woolgar. ${ }^{4}$ It is true that in the anthropological section of their book mention is made of rotary evaporators, centrifuges, shakers, grinders and other 'machines', which the lab staff at the Salk Institute use to cut, sew, shake and mix the organic material they need. Yet the main part of the anthropological section is devoted to the desks upon which various kinds of literature accumulate - published journal articles, computer printouts with columns of figures, diagrams and tables, manuscripts and so forth - that are then transformed into scientific publications.

Latour and Woolgar make it quite clear that from the perspective of anthropology it is the literary inscription that is the 'prototype of scientific work in the laboratory' (Latour and Woolgar, 1979: 47). For the authors laboratory work is primarily and principally ongoing work on and with texts through which process the different types of statements are converted into factual or non-factual: 'the work of the laboratory can be understood in terms of the continual generation of a variety of documents, which are used to effect the transformation of statement types and so enhance or detract from their fact-like status' (ibid.: 151).

In this context 'inscriptions' denote not only words but also 'traces, spots, points, histograms, recorded numbers, spectra, peaks, and so on' (1979: 88). For this concept of inscription Latour and Woolgar refer to the generalized concept of writing of Jacques Derrida. However, the central concept of their anthropology chapter is not writing, but literature. According to the authors this concept 'refers both to the central importance accorded a variety of documents and to the use of equipment to produce inscriptions which are taken to be about a substance, and which are themselves used in the further generation of articles and papers' (ibid.: 63).

In other words the focus is on laboratory texts, their storage, arrangement, processing and production, and at the same time it is on the meaning, import and validity that are accorded these texts and the material and inscriptions that went into them within the laboratory contexts. In Péguy fashion one could say that Laboratory Life examines a certain 'cult of the inscription'; a cult in which inscription may not be taken for the action, but it is at least taken for the thing, the fact.

Clearly a question of belief is at issue here: not the belief in writing, but the belief in science. According to Latour and Woolgar it is in effect practices of explanation and interpretation - 'local tacit negotiations, constantly changing evaluations, and unconscious or institutionalized gestures' - which nurture and consolidate 'a belief in the logical and straightforward character of science' (1979: 151-2) within the laboratory. For precisely this reason Laboratory Life does not simply open up scientific texts to exegesis in the classic sense, although the authors cite Bultmann's History of the Synoptic Tradition (1963; first published in German in 1921) when they attempt to tap into the social context of scientific 'stories' of various genres (Latour and Woolgar, 1979: 185). Rather, the laboratory, as a whole, is an institution serving the purpose of tradition and transmission, where exegeses, rereadings and revisions, both written and oral, are constantly taking place that refer to laboratory events grounded in the organisms and machines.

It is as if Latour's vertical reading of Péguy has been turned a further 90 degrees: the differentiating repetitions of what has come down as tradition are no longer related to a 


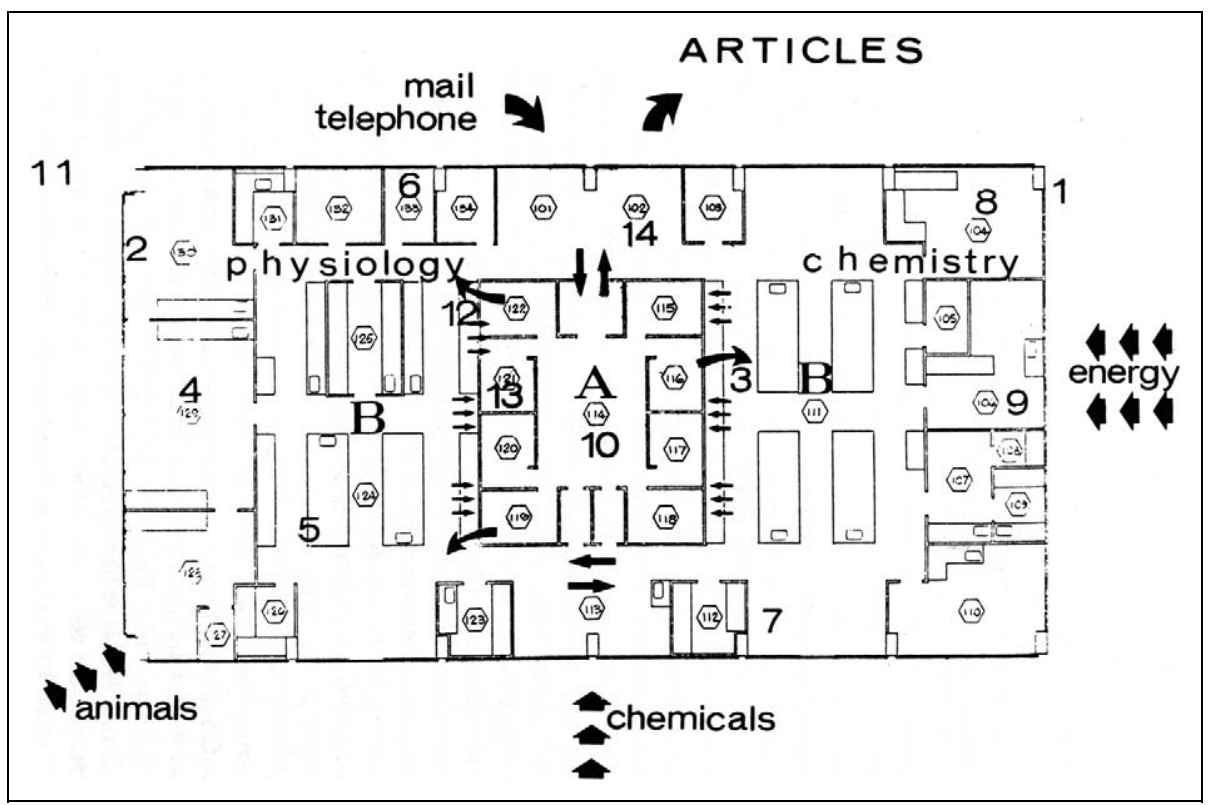

Figure 2. Diagram of the Neuroendocrinology Laboratory at the Salk Institute, La Jolla, CA, in 1979. Section $A$ is where work on and with texts is done; section $B$ is where physiological/chemical work is performed on organisms and with machines. Arrows indicate the relations between the two sections. The main product of work in the laboratory is scientific papers. The numerals denote the photographs in the book that supplement the diagram.

(Source: Latour and Woolgar, 1979: 46)

religious event in the depths of time but to scientific incidents in proximate segments of space. Or at least this is what the book's first figure appears to suggest. It offers a cartography of the laboratory's exegetic architecture (Fig. 2).

Texts are read and written in the centrally located section A, where there are only desks, articles and reference works on concepts and materials; next door, in section B, is where work with instruments, equipment and machines takes place. As a result, the initial question reads: "What is the relationship between Section A ("my office", "the office", "the library") and Section B ("the bench")' (1979: 45)? Or phrased differently: How is the 'series of transformations' constituted (ibid.: 50) by which the events taking place in section B through interaction of organisms and machines finally find their way, via inscription devices and other methods of reading and registering, to the piles of paper in section A, from whence as the literary end-products of work in the laboratory they make their way to science journals, textbooks and collections of essays? As a result, the problem of tradition in space becomes a question of 'reference', as Latour (1995) calls it in his later study on the work of soil scientists in the area around Boa Vista in the Amazon, Brazil.

However, the way in which Laboratory Life answers the question concerning the relationship between sections A and B shows (in rather Péguyesque terms) that, eventually, the boundary between machines and desks is not as clear as the architectural layout 
suggests. For not only space, but also time, plays a role. This is particularly evident in chapter 2, i.e. the historical case study on the 'construction' of a scientific fact. The subject of this case study is the determining and synthesizing of the thyrotropin-releasing factor (TRF) or thyrotropin-releasing hormone (TRH) by Roger Guillemin and Andrew Schally in the late 1960s. In view of this work, which culminated in TRF/TRH, Latour and Woolgar show that the 'construction' of a 'new object' in the laboratory is initially tied to repetition and similarity. According to them, these criteria are decisive for whether first assumptions and first propositions can be confirmed experimentally. In the area of relative reliability that results, differences emerge whose observation and study then leads to innovation.

Now for Latour and Woolgar repetitions and differences are inextricably associated with inscriptions to which, in their view, the genesis of new scientific objects is linked. According to this the construction of a scientific fact is essentially a matter of differing inscriptions: 'It is not simply that differences between curves indicate the presence of a substance; rather the substance is identical with perceived differences between curves' (Latour and Woolgar, 1979: 128). Or expressed more generally: 'An object can be said to exist solely in terms of the difference between two inscriptions' (ibid.: 127).

The new, the novel, thus occurs at the interface between machines and writing desks in a space that is at once material and immaterial; that is, in a certain sense this space lies somewhere before this differentiation, is located beyond it: in view of the inscription devices' which are situated halfway between the world of centrifuges and mixers in section B and the world of pens and paper in section A.

At this point, Latour's reading of Péguy appears to have undergone a further turning of 90 degrees. It has been turned upside-down. Differences in writings that have been passed on no longer refer to an event in the depths of time, or to an incident in another sector of space. The laboratory researcher acts quite in accordance with the 'correct reader' in the sense used by Péguy, who persuades this reader, through the 'ex-habitual' reading of inscriptions, to start over again once more. The reader makes out of the inscriptions an event which approaches him or her in the present moment. Only the direction has changed: the distance, from whence the event approaches, lies no longer in the past but in the future. Repetition here interiorizes and thereby reverses itself, as one might say with Deleuze. Repetition is not any more understood as an unvarying retrogression to something, but as a process that is open in a forward direction, which is grounded in, initiated and continued by an event. However, this event is not something that is referred to; it is itself a reference, a sign, a difference.

It is precisely here that the historic case study in Laboratory Life combines itself with an historiographic argument. Latour and Woolgar assume that the inscription differences create a new space and give rise to a new time: a space in which TRF/TRH has become a fact, which now other laboratories take as a 'given' with which they can work; a time in which a world without the existence of TRF/TRH is quasi-unthinkable, for scientists tend to forget their innovative exegeses and start to project the existence of the new object back in time.

History of science participates in this new time. According to Latour and Woolgar, when science historians reconstruct episodes that lead to new scientific facts they take the established fact as their starting point and then project its constant existence back 
onto the historical process. Historians of science tend to describe the activities of scientists in a terminology that takes for granted the pre-existence of the objects or truths, which merely have to be 'discovered' or 'disclosed'. Further, they often proceed on the assumption of a simple and unproblematic relation between signs and signified things. For the authors it follows that 'Most of the time, historical reconstructions miss the process of solidification and inversion whereby a statement becomes a fact' (1979: 106).

In order to arrive at an adequate description of practices in science, it is necessary to change the focus from product to process. As Latour and Woolgar put it, 'the formulations which characterize historical descriptions of scientific practice require exorcism before the nature of this practice can be best understood' (1979: 129). To this end they take pains to avoid all expressions that could potentially change the character of the processes and phenomena examined. Latour and Woolgar attempt to find elements of a new language which does justice to the 'artful creativity' of laboratory scientists. And they especially try to do full justice to those research situations in which there are no charted paths (ibid.: 128, 129, 106).

It is interesting to note that these arguments endow the expression 'construction of scientific facts' with important nuances. On the one hand this rather bold expression represents a strong contrast to the view that science practices are about 'discoveries' or 'disclosures', and on the other 'construction' cannot simply be understood as planned building or programmed manufacture, but rather in a more emphatic sense as the creation of something new. This is why Latour and Woolgar insist: 'to say that TRF is constructed is not to deny its solidity as a fact' (1979: 127). More generally, they add: 'Our argument is not that facts are not real, nor that they are merely artificial' (ibid.: 176).

The hybrid ontological status, the 'mode of existence' of scientific objects between construction and facticity, Latour attempts to pin down more exactly in later works; for example, when he speaks about the fundamental antinomy embodied in scientific facts: 'facts are experimentally made up and never escape from their man-made settings; it is essential that they are not made up and that something emerges which is not man-made' (Latour, 1990: 64; original emphasis). Or when he says that in order to be able to write the history of a scientific object one has to assume that it 'must be in part causa sui' and adds that 'All actual entities share with God this characteristic of self-causation' (Latour, 1996: 88).

The God that is mentioned here, of course, is not the personified God of the Roman Catholic religion. Quoting Whitehead, Latour here speaks of God as the omega, the absolute, a principle, who is only characterized by his actual embodiments. Thus God means something akin to 'creativity' (Whitehead, 1978: 223; in this context, see also Debaise, 2006: 37-57). It is only because the objects of science are creations - they spring from humans but at the same time transcend or transgress them - that they are accorded a history of their own. Otherwise they could be simply subsumed under social history or the history of ideas: as mere constructions or mere discoveries.

\section{Infectious exegesis}

The Pasteurization of France proceeds further down this path of 'irreductionism'. The book takes the historiographic arguments from Laboratory Life to make them more 
pointed. To begin with, Latour does this by setting his book off from the discipline of history. Although The Pasteurization of France engages with source material from the history of science Latour emphasizes from the outset that he is not operating as a historian:

I cannot claim [the honour] of being a historian. ... I use history as a brain scientist uses a rat, cutting through it in order to follow the mechanisms that may allow me to understand at once the content of a science and its context. (Latour, 1988: 12; original emphases)

Paradoxically, this alleged laboratory researcher-type approach to historical material - in this case, texts on bacteriology published between 1870 and 1919 in Revue Scientifique, Annales de l'Institut Pasteur and Concours Médical - serves to facilitate an 'agnostic' approach to science and its history. Just as Spinoza became an agnostic with regard to the Bible in order to write the exegetic section of his Theologico-Political Treatise, Latour states that the Pasteur scholar has to become an agnostic towards his sources, albeit in a different sense: 'belief in the sciences, like the old belief in God, is a superfluous hypothesis' (1988: 7).

Elsewhere Latour formulates this rejection of the belief in science normatively:

If you share materially the vested interests of the scientific establishment and share intellectually the beliefs and ethos of science (no matter which ones), you lose the right to explain what science is all about; you can only repeat it and add a science to the other sciences. (Latour, 1981: 205; original emphasis)

Such an imitation of science, says Latour, has no explanatory value; similar to how a quotation from Péguy amounts to taking up again an enigmatic text in a commonplace sense. The suspension of belief in science thus serves the greatest possible proximity to science as something non-commonplace, mysterious.

The greater the distance to science, the more light can be shed on science? According to Latour the most fruitful insights into the structure and function of science are indeed indebted to authors who already in their style distance themselves from science: for example, Paul Feyerabend and Michel Serres, and also Robert Musil (see 1981: 211, 206). Consequently, The Pasteurization of France does not open with a look at science or research but with the paraphrase of a passage from Tolstoy's novel War and Peace.

In the same way as Latour enlists the help of Lévi-Strauss in his study on Péguy for a 'non-literary' approach and takes great care in Laboratory Life (with Woolgar) not to distort the observed processes through the expressions employed, he chooses in this case the most 'non-scientific' approach conceivable - precisely in order to do better justice to science as a phenomenon.

Latour underlines this point when he discusses in which terminology science can be handled:

I must admit that there is no established stock of such concepts [that would make our explanations independent of the science under study], especially not in the so-called human sciences, particularly sociology. Invented at the same period and by the same people as 
scientism, sociology is powerless to understand the skills from which it has so long been separated. Of the sociology of the sciences I can therefore say, 'Protect me from my friends, I shall deal with my enemies', for if we set out to explain the sciences it may well be that the social sciences will suffer first. What we have to do is not to explain bacteriology in sociological terms but to make those two logoi once more unrecognizable. (Latour, 1988: 9; original emphasis)

Agnosticism in science studies apparently reaches its limits here. It aims to situate itself beyond the commonalities and oppositions of natural sciences, social sciences and humanities in order not to reduce 'science' to another variable - not to society, economics, language games, laws, mechanisms, or systems (see 1988: 203-6). However, the endeavour that Latour actually undertakes is to bring two disciplines together - sociology and bacteriology - via the examination of historical texts in a zone of 'indiscernibility' (as one can express it following Deleuze and Guattari [1994(1991): 207]), in which there can be a renewed thinking about science.

As a consequence, Latour's project leads to a renewal of sociology (of science) in the spirit of bacteriology:

Just as the Pasteurians reshuffled the distribution of actors between nature, science, and society by the temporary formation of the microbe-whose-virulence-one-can-vary-in-thelaboratory, we must ... redistribute ... what belongs to nature, the sciences, and societies. (Latour, 1988: 149)

Thus 'how to follow scientists and engineers through society' (the subtitle of Science in Action) should not be understood as merely following upon the heels of these specialists; part of the task is to take on the concrete perspective of scientists (and engineers) vis-àvis society, to internalize it - especially in those cases where it appears alien and strange. How else should we understand Latour's attempt to reconstruct the texts and contexts of the Pasteurians 'from within'? How else can one interpret his famous remark 'I have spoken of the Pasteurians as they spoke of their microbes' (1988: 114, 148)?

The perspectives of a sociology that draws stimulation in this manner from an encounter with bacteriology do not need to be investigated here. It is sufficient to call to mind Gabriel Tardes' 'mass psychology', well-regarded by Latour, and the importance it accords to the phenomenon of contagion, as well as the social theory of the cell, also well-regarded by Latour, which has recently been developed by the virologist Pierre Sonigo (see e.g. Mayer and Latour, 2005: 98; Latour, 2004: 23; Kupiec and Sonigo, 2003). More illuminating at this point is the fact that, according to Latour, sociology is not the only discipline that is changed by an encounter with bacteriology. Something similar happens to the other discipline whose scientific quality he invokes - in spite of the demand for agnosticism - at the beginning of the Pasteurization book: exegesis.

In this connection, too, the terms used must not stand in contradiction to the task in hand: to comprehend and explain the activities of the Pasteurians 'from within'. Thus when Latour insists that 'The only task of the analyst is to follow the transformations that the actors convened in the stories [i.e. the scientific publications in question] are undergoing' (Latour, 1988: 114, 10), it is not so much a rough semiotic instruction of how to 
proceed, but more an outline of a half-exegetic, half-bacteriological method with which the phenomenon of tradition is reconceptualized in the sense of transmission and transfer; an infection that occurs not only between the bodies of texts, but also inside these bodies.

According to Latour it is not he but rather Pasteur and his disciples who define the actor-networks with their texts by continually infecting other actors with agency (see e.g. Latour, 1988: 102). Do we have to do, then, with a microbiologically inspired theory of inter- and intra-textual tradition, similar to Serres' (1982) parasitologically inspired theory of communication? Possibly. At least one can say that The Pasteurization of France reiterates Latour's Péguyesque gesture. The initial distance built up to the historical material of study changes again into proximity, into an affiliation.

\section{Conclusion}

Latour approaches the topics of his work with a curiosity and openness that appear to be radical. The strategy that he employs can be characterized succinctly as follows: Build up a distance to achieve proximity. In his study of Péguy, Latour selects a reading raster and schemata to attain the greatest possible distance between commentary and what is commented on to meet the criteria of 'reading correctly'; the result is a congenial reading of Péguy that manifests itself as a differentiating repetition. In Laboratory Life, diagrams and photographs are used to gain distance to the work on texts in the laboratory; further, great care is taken to ensure that the authors' terminology does not falsify the developmental process of scientific facts. The result is to understand the literary end-products of work in the laboratory not as mere fabrication, but as ingenious creations. In The Pasteurization of France Latour assumes the perspective of a novelist in order to describe text and context of Pasteur's scientific endeavours; this results in a novel, bacteriology-inspired sociology and exegesis of science.

Latour constantly assumes a role to begin with - ethnologist, sociologist, historian - so that he then gets as close as possible to the literary and scientific texts that interest and fascinate him. One is tempted to describe him as a disciple of Bertolt Brecht's, who employs certain disciplines - sociology, history, etc. - as alienation or distancing effects [Verfremdungseffekte] to allow other disciplines, which are standing next to him on the stage, to have their say, to be rendered more visible (in a similar vein, see Zammito, 2004: 152).

However, Latour himself chooses a different terminology to describe the position upon which his agnostic access to science and its history is based:

Science deserves better than naive worship and naive contempt. Its regime of invisibility is as uplifting as that of religion or art. The subtlety of its traces requires a new form of care and attention. It requires - why abstain from the word? - yes, spirituality. (Latour, 2002b: 34)

Thus it is not surprising that the objects of science do not appear in his work primarily as material objects. Obviously TRF/TRH can also be manipulated and transported, but this is a secondary consideration for Latour. First and foremost is the particular mode of existence of scientific objects: as threshold entities between the fabricated and the factual, between the historical and the logical, between the profane and the divine. It is about events which occur in a certain form of exegesis, about differences of inscriptions, which 
in a specific way change the texts and their readers, and even the libraries where reading and exegesis take place.

To be sure, Latour is not the first or only science scholar to observe and discuss the specificity of scientific things. In this connection others have written of the 'surreality' of scientific objects and drawn attention to the 'incompleteness' of the character of their effects and reality (Canguilhem, 1977: 114). Along similar lines, other authors have made an issue of and discussed the 'production and creation of phenomena' in the laboratory (Hacking, 1983: 220-32). However, Latour is one of the few authors who speaks of transcendence and spirituality in this context. Contemporary history of science has great difficulties with this topos, this idiom - even when, or specifically when, it cautiously and attentively engages with the assemblage of 'material traces' created by and in experiments (Rheinberger, 1997: 105).

In addition, an important focus of current work in the history of science remains the 'material culture' of scientific practice and the issue of 'material agency' in the laboratory. In fact, the potentials of a materialism, which poses the question of difference and repetition in science more from the angle of machine production than from literary representations, and regards scientific facts more in the sense of effects than in the sense of objects, seem by no means to be exhausted.

Latour's actuality and his problematic lie in different terrain. In a situation that is marked by keywords such as 'creationism' and 'fundamentalism' the parallel look at science and religion, history and gospels, proves to be an enormously fruitful heuristic. This was demonstrated in striking ways by Iconoclash, the exhibition co-curated by Latour and Peter Weibel (2002) on the world 'beyond the image wars in science, religion, and the arts'. Confronted by the almost excessive fruitfulness of this show, however, one does recall Deleuze's reservations about the philosophy of Péguy as a culmination of Kantianism. The ultimate question is whether it is instructive to speak of 'belief' in connection with science.

Latour provides no answer to this question. He is too much the masked philosopher, the thinker on a stage. His aim is not historical reconstruction, a causal and explanatory account. Latour is concerned with dissuasion away from the discipline of history, away from materialism and away from the history of science. The glad tidings he brings are that the openness of the event is perennial.

\section{Notes}

I would like to thank Gloria Custance, Laura Otis and Lynn Badia for their help in preparing the English version of this article. For critical readings, comments and discussions I thank Hans-Jörg Rheinberger, Gustav Roßler, Andrew Pickering, Michael Lynch, Robyn Braun, Didier Debaise and Bruno Latour.

1. Unless otherwise stated, all translations from the German and the French are my own.

2. The overall argument developed here was first published in the German language (Schmidgen, 2008). A revised English-language version was presented at the European meeting of the Society for Science, Literature and the Arts (SLSA), 3-7 June 2008, in Berlin. This presentation was part of a panel entitled 'Angels, Saints, and Evangelists: Three Untimely Meditations on Bruno Latour and the Problem of Time' that the author co-organized with Joan A. Richardson and Steven Meyer. After having read this early version of the present article, Latour responded 
in an email to the author (16 July 2008) that he was intrigued by the connections between the exegesis of Clio and that of science ('which is exactly right') and generously provided additional information concerning his early training. Meanwhile, the author of this article has further developed his argument into a book-length study (Schmidgen, 2011). The present version of the article has been updated and revised accordingly.

3. However, already in his early anthropological work concerning the problem of industrial competence in Abidjan (Côte d'Ivoire), Latour enters into a discussion about some of the crucial concepts developed by Deleuze and Guattari (1983[1972]), e.g. the famous couple 'deterritorialization/reterritorialization' (see Latour and Shabou, 1974: 75). Contrary to what is said in Latour's autobiographical note (2010: 601), one may add that Deleuze's discussion of Péguy was published some years before Latour submitted his thesis on Péguy and the New Testament (see Deleuze, 1990[1969]; 1994[1968]).

4. Latour and Woolgar started their collaboration after Latour had completed most of his field studies at the Salk Institute for Biological Studies in the fall of 1977. Trained by science sociologist Michael Mulkay, Woolgar shared Latour's interest in the analysis of research networks, scientific discourses and rhetorical strategies (see, for example, Woolgar, 1976).

\section{References}

Benjamin, W. (1994) 'To Gerhard Scholem, Klosters, September 15, 1919', in G. Scholem and T.W. Adorno (eds) The Correspondence of Walter Benjamin, 1910-1940, trans. M. R. Jacobson and E. M. Jacobson. Cambridge, MA and London: Belknap Press of Harvard University Press, pp. 146-7.

Benjamin, W. (2002) 'Eduard Fuchs, Collector and Historian', in W. Benjamin, Selected Writings, vol. 3, 1935-1938, ed. H. Eiland and M. W. Jennings, trans. E. Jephcott Cambridge, MA and London: Belknap Press of Harvard University Press, pp. 260-302.

Bormuth, M. and von Bülow, U., eds (2008) Marburger Hermeneutik zwischen Tradition und Krise [Marburg Hermeneutics between Tradition and Crisis]. Göttingen: Wallstein.

Bowker, G. and Latour, B. (1987) 'A Becoming Discipline Short of Discipline: (Social) Studies of Science in France', Social Studies of Science 11: 715-48.

Bultmann, R. (1963) The History of the Synoptic Tradition, trans. J. Marsh. Oxford: Blackwell.

Bultmann, R. (1973) Histoire de la tradition synoptique [The History of the Synoptic Tradition], trans. A. Malet. Paris: Seuil.

Bultmann, R. and Heidegger, M. (2009) Briefwechsel 1925 bis 1975 [Correspondence 1925 to 1975], ed. A. Großmann and C. Landmesser. Frankfurt am Main: Klostermann.

Canguilhem, G. (1977) Idéologie et rationalité dans l'histoire des sciences de la vie: Nouvelles études d'histoire et de philosophie des sciences [Ideology and Rationality in the History of the Life Sciences: New Studies in the History and Philosophy of the Sciences]. Paris: Vrin.

Certeau, M. de (1971) 'La rupture instauratrice ou le christianisme dans la culture contemporaine' [The Instaurational Rupture or Christianism in Contemporary Culture], Esprit NS 6: 1177-1214.

Crawford, T. H. and Latour, B. (1993) 'An Interview with Bruno Latour', Configurations 1(2): 247-68.

Curtius, E. R. (1919) 'Charles Péguy', in E. R. Curtius, Die literarischen Wegbereiter des neuen Frankreich [The Literary Precursors of the New France]. Potsdam: Kiepenheuer, pp. 195-235.

Debaise, D. (2006) Un empirisme spéculatif: Lecture de Procès et réalité de Whitehead [A Speculative Empricism: Reading Whitehead's Process and Reality]. Paris: Vrin. 
Deleuze, G. (1990[1969]) The Logic of Sense, ed. C. V. Boundas, trans. M. Lester, with C. Stivale. New York: Columbia University Press.

Deleuze, G. (1994[1968]) Difference and Repetition, trans. P. Patton. New York: Columbia University Press.

Deleuze, G. and Guattari, F. (1977) 'Balance Sheet-Program for Desiring Machines', trans. R. Hurley, Semiotext(e) 2(3): 117-35.

Deleuze, G. and Guattari, F. (1983[1972]) Anti-Oedipus: Capitalism and Schizophrenia, preface M. Foucault, trans. R. Hurley, M. Seem and H. P. Lane. Minneapolis: University of Minnesota Press.

Deleuze, G. and Guattari, F. (1994[1991]) What Is Philosophy?, trans. H. Tomlinson and G. Burchell. New York: Columbia University Press.

Dosse, F. (2002) Michel de Certeau. Le marcheur blessé [Michel de Certeau: The Wounded Walker]. Paris: La Découverte.

Durkheim, E. (2008[1912]) The Elementary Forms of Religious Life, trans. C. Cosman. Oxford and New York: Oxford University Press.

Erdély, P. (2011) 'Foreword', in B. Latour, G. Harman and P. Erdély, The Prince and the Wolf: Latour and Harman at the LSE. Winchester, Hants: Zero Books, pp. 1-20.

Galison, P. (1997) Image and Logic: A Material Culture of Microphysics. Chicago, IL: Chicago University Press.

Golinski, J. (1990) 'The Theory of Practice and the Practice of Theory: Sociological Approaches in the History of Science', Isis 81: 492-505.

Golinski, J. (2010) 'Science and Religion in Postmodern Perspective: The Case of Bruno Latour', in T. Dixon, G. Cantor and S. Pumfrey (eds) Science and Religion: New Historical Perspectives. Cambridge: Cambridge University Press, pp. 50-68.

Hacking, I. (1983) Representing and Intervening: Introductory Topics in the Philosophy of Natural Science. Cambridge: Cambridge University Press.

Harman, G. (2009) Prince of Networks: Bruno Latour and Metaphysics. Melbourne: Re.press.

Hennion, A. and Latour, B. (2003) 'How to make Mistakes on So Many Things at Once - and become Famous for It', in H. U. Gumbrecht and M. Marrinan (eds) Mapping Benjamin: The Work of Art in the Digital Age. Stanford, CA: Stanford University Press, pp. 91-7.

Holland, E. (1999) Deleuze and Guattari's Anti-Oedipus: Introduction to Schizoanalysis. London: Routledge.

Kierkegaard, S. (1983[1843]) 'Repetition: a Venture in Experimenting Psychology', in S. Kierkegaard, Fear and Trembling/Repetition, ed. and trans. H. V. Hong and E. H. Hong. Princeton, NJ: Princeton University Press, pp. 125-231.

Kochan, J. (2010) 'Latour's Heidegger', Social Studies of Science 40(4): 579-98.

Kühn, R. (1993) 'Claude Bruaire und die Geistesphilosophie als "Ontodologie”, [Claude Bruaire and Philosophy of Mind as 'Ontodology'], in R. Kühn, Französische Reflexions- und Geistesphilosophie: Profile und Analysen [French Philosophy of Mind and Reflection: Profiles and Analyses]. Frankfurt am Main: Hain, pp. 157-71.

Kupiec, J.-J. and Sonigo, P. (2003) Ni dieu ni gène: Pour une autre théorie de l'hérédité [Neither God nor Gene: Toward a Different Theory of Heredity]. Paris: Seuil.

Latour, B. (1975) 'Exegèse et ontologie à propos de la resurrection' [Exegesis and Ontology with Respect to the Resurrection], thèse de $3^{\mathrm{e}}$ cycle sous la direction de Claude Bruaire [ $\mathrm{PhD}$ thesis under the direction of Claude Bruaire], Université de Tours (unpublished). 
Latour, B. (1977) 'Pourquoi Péguy se répète-t-il? Pourquoi est-il illisible?' [Does Péguy Repeat Himself? Why is he Unreadable?], in Péguy écrivain: Colloque du centenaire, Orléans, septembre 1973 [Péguy, the Writer: Centennial Colloquium, Orléans, September 1973]. Paris: Klincksieck, pp. 76-102.

Latour, B. (1981) 'Insiders \& Outsiders in the Sociology of Science; or, How can We foster Agnosticism?', in Knowledge and Society: Studies in the Sociology of Culture Past and Present, vol. 3, ed. R. A. Jones and H. Kucklick. Greenwich, CT: JAI Press, pp. 200-16.

Latour, B. (1988) The Pasteurization of France, trans. A. Sheridan and J. Law. Cambridge, MA: Harvard University Press.

Latour, B. (1990) 'The Force and Reason of Experiment', in H. E. Le Grand (ed.) Experimental Inquiries: Historical, Philosophical and Social Studies of Experimentation in Science. Dordrecht, Boston, MA and London: Kluwer, pp. 49-80.

Latour, B. (1993a) We Have Never Been Modern, trans. C. Porter. Cambridge, MA: Harvard University Press.

Latour, B. (1993b) 'Les anges ne font pas de bons instruments scientifiques' [Angels do not function as Good Scientific Instruments], in B. Latour, La clefde Berlin et autres leçons d'un amateur des sciences [The Berlin Key and Other Lessons from an Amateur of Science]. Paris: La Découverte, pp. 226-52.

Latour, B. (1995) 'The "Pedofil" of Boa Vista: a Photo-Philosophical Montage', Common Knowledge 4(1): 145-87.

Latour, B. (1996) 'Do Scientific Objects have a History? Pasteur and Whitehead in a Bath of Lactic Acid', Common Knowledge 5(1): 76-91.

Latour, B. (1997) 'Trains of Thought: Piaget, Formalism and the Fifth Dimension', Common Knowledge 6(3): 170-91.

Latour, B. (1999) Pandora's Hope: Essays on the Reality of Science Studies. Cambridge, MA and London: Harvard University Press.

Latour, B. (2002a) Jubiler - ou les tourments de la parole religieuse [Jubilate - or, the Torments of Religious Speech]. Paris: Les Empêcheurs de penser en rond and Seuil.

Latour, B. (2002b) 'What is Iconoclash? Or is There a World beyond the Image Wars?', in B. Latour and P. Weibel (eds) Iconoclash: Beyond the Image Wars in Science, Religion, and the Arts. Karlsruhe and Cambridge, MA: ZKM and MIT Press, pp. 14-37.

Latour, B. (2004) 'Von "Tatsachen" zu "Sachverhalten": Wie sollen die neuen kollektiven Experimente protokolliert werden?' [From 'Matters of Fact' to 'Matters of Concern': Which Protocol for the New Collective Experiments?], trans. G. Roßler, in H. Schmidgen, S. Dierig and P. Geimer (eds) Kultur im Experiment [Culture in/as Experiment]. Berlin: Kadmos, pp. 17-36.

Latour, B. (2005) " "Thou shall [sic] not freeze-frame”, or, How Not to misunderstand the Science and Religion Debate', in J. D. Proctor (ed.) Science, Religion, and the Human Experience. Oxford: Oxford University Press, pp. 27-48.

Latour, B. (2007) 'Can We get Our Materialism back, Please?', Isis 98: 138-42.

Latour, B. (2010) 'Coming out as a Philosopher', Social Studies of Science 40(4): 599-608.

Latour, B. and Shabou, A. (1974) Les idéologies de la compétence en milieu industriel à Abidjan [The Ideologies of Competence in the Industrial World of Abidjan], in 'Sciences Humaines, Série études industrielles', vol. 9. Abidjan: ORSTOM.

Latour, B. and Weibel, P., eds (2002) Iconoclash: Beyond the Image Wars in Science, Religion, and the Arts. Karlsruhe and Cambridge, MA: ZKM and MIT Press. 
Latour, B. and Woolgar, S. (1979) Laboratory Life: The Social Construction of Scientific Facts. Beverly Hills, CA: Sage.

Lenoir, T. (1994) 'Was the Last Turn the Right Turn? The Semiotic Turn and A. J. Greimas', Configurations 2(1): 119-36.

Lévi-Strauss, C. (1970-81) Introduction to the Science of Mythology, vols I-IV. New York: Harper \& Row.

Malet, A. (1962) Mythos et logos: La pensée de Rudolf Bultmann [Mythos and Logos: The Thought of Rudolf Bultmann]. Geneva: Labor et Fides.

Malet, A. (1966) Le traité théologico-politique de Spinoza et la pensée biblique [Spinoza's Tractatus Theologico-Politicus and Biblical Thought]. Paris: Société Les Belles Lettres.

Malet, A. (1968) Bultmann et la mort de Dieu: Présentation, choix de textes, biographie, bibliographie [Bultmann and the Death of God: Presentation, Choice of Texts, Biography, Bibliography]. Paris: Seghers.

Mayer, A. and Latour, B. (2005) 'Vom Widerstand der Dinge: Bruno Latour im Gespräch mit Andreas Mayer über symmetrische Anthropologie, die Suspendierung des Sozialen, ANT, das Phantom und einige Mißverständnisse' [On the Resistance of Things: Bruno Latour in Conversation with Andreas Mayer about Symmetrical Anthropology, the Suspension of the Social, ANT, the Phantom and Some Misunderstandings], Die Neue Rundschau 116(3): 93-102. Nowotny, H. (1994) Time: The Modern and Postmodern Experience, trans. N. Plaice. Cambridge, MA: Polity Press.

Péguy, C. (1959) 'De la situation faite à l'histoire et à la sociologie dans les temps modernes' [On the Situation created for History and Sociology in Modernity], in C. Péguy Euvres en prose, 1898-1908 [Works in Prose, 1898-1908]. Paris: Gallimard, pp. 991-1030.

Péguy, C. (1961a) 'Note sur M. Bergson et la philosophie bergsonienne' [Note on Mr Bergson and Bergsonian Philosophy], in C. Péguy, Euvres en prose, 1909-1914 [Works in Prose, 1909-1914]. Paris: Gallimard, pp. 1311-1552.

Péguy, C. (1961b) 'Clio: Dialogue de l'histoire et de l'âme païenne' [Clio: Dialogue between History and the Pagan Soul], in C. Péguy, Euvres en prose, 1909-1914 [Works in Prose, 1909-1914]. Paris: Gallimard, pp. 93-308.

Péguy, C. (1961c) 'Veronique: Dialogue de l'histoire de l'âme charnelle' [Veronica: Dialogue between History and the Earthly Soul], in C. Péguy, Euvres en prose: 1909-1914 [Works in Prose, 1909-1914]. Paris: Gallimard, pp. 309-500.

Péguy, C. (1961d) 'Un nouveau théologien, M. Fernand Laudet' [A New Theologian, Mr Fernand Laudet], in C. Péguy, Euvres en prose, 1909-1914 [Works in Prose, 1909-1914]. Paris: Gallimard, pp. 893-1095.

Pickering, A. (1995) The Mangle of Practice: Time, Agency and Science. Chicago, IL and London: Chicago University Press.

Rheinberger, H.-J. (1997) Toward a History of Epistemic Things: Synthesizing Proteins in the Test Tube. Stanford, CA: Stanford University Press.

Riis, S. (2008) 'The Symmetry between Bruno Latour and Martin Heidegger: The Technique of Turning a Police Officer into a Speed Bump', Social Studies of Science 38(2): 285-301.

Roßler, G. and Latour, B. (1997) 'Ein neuer Empirismus, ein neuer Realismus: Bruno Latour im Gespräch mit Gustav Roßler' [A New Empricism, a New Realism: Bruno Latour in Conversation with Gustav Roßler], Mittelweg 6(36): 40-52. 
Sarasin, P. (2003) 'Infizierte Körper, kontaminierte Sprachen: Metaphern als Gegenstand der Wissenschaftsgeschichte' [Infected Bodies, Contaminated Languages: Metaphors as an Object for the History of Science], in P. Sarasin, Geschichtswissenschaft und Diskursanalyse [History and Discourse Analysis]. Frankfurt am Main: Suhrkamp, pp. 191-230.

Schaffer, S. (1991) 'The Eighteenth Brumaire of Bruno Latour', Studies in History and Philosophy of Science 22(1): 174-92.

Scheler, M. (1924) 'Probleme einer Soziologie des Wissens' [Problems of a Sociology of Knowledge], in M. Scheler (ed.) Versuche zu einer Soziologie des Wissens [Attempts at a Sociology of Knowledge]. Munich and Leipzig: Duncker \& Humblot, pp. 1-146.

Schmidgen, H. (2008) 'Die Materialität der Dinge: Bruno Latour und die Wissenschaftsgeschichte' [The Materiality of Things: Bruno Latour and the History of Science], in G. Kneer, M. Schroer and E. Schüttpelz (eds) Bruno Latours Kollektive: Kontroversen zur Entgrenzung des Sozialen [Bruno Latour's Collectives: Controversies about Transgressing the Social]. Frankfurt am Main: Suhrkamp, pp. 15-46.

Schmidgen, H. (2011) Bruno Latour: Zur Einführung [Bruno Latour: An Introduction]. Hamburg: Junius.

Serres, M. (1982) The Parasite, trans., with notes, L. R. Schehr. Baltimore, MD: Johns Hopkins University Press.

Shapin, S. (1988) 'Following Scientists around', Social Studies of Science 18: 533-50.

Shortland, M. (1998) 'Michel Serres, passe-partout' [Michel Serres, the Passkey], British Journal for the History of Science 31: 335-53.

Spitzer, L. (1928) 'Zu Charles Péguys Stil' [On Charles Péguy's Style], in L. Spitzer, Stilstudien, Zweiter Teil: Stilsprachen [Studies on Style, part two: Languages of Style]. Munich: Hueber, pp. 301-64.

Thill, G. (1973) La fête scientifique: D'une praxéologie scientifique à une analyse de la decision chrétienne [The Scientific Celebration: From a Praxeology of Science to an Analysis of the Christian Decision]. Paris: Aubier-Montaigne.

Tiedemann-Bartels, H. (1986) Verwaltete Tradition: Die Kritik Charles Péguys [Administered Tradition: The Criticism of Charles Péguy]. Freiburg: Alber.

Villiers, M. (1965) Charles Péguy: A Study in Integrity. London: Collins.

Whitehead, A. N. (1978) Process and Reality: An Essay in Cosmology. New York: Free Press. Woolgar, S. W. (1976) 'The Identification and Definition of Scientific Collectivities', in G.Lemaine, R. MacLeod, M. Mulkay and P. Weingart (eds) Perspectives on the Emergence of Scientific Disciplines. The Hague: Aldine, pp. 234-45.

Zammito, J. R. (2004) A Nice Derangement of Epistemes: Post-positivism in the Study of Science from Quine to Latour. Chicago, IL: University of Chicago Press.

\section{Author biography}

Henning Schmidgen is Professor of Media Aesthetics at Regensburg University. From 1997 to 2011, he was a research scholar at the Max Planck-Institute for the History of Science in Berlin. He has just finished a comprehensive account of physiological and psychological time experiments in the 19th and early 20th centuries. Recent books include Die Helmholtz-Kurven: Auf der Spur der verlorenen Zeit [The Helmholtz Curves: Tracing Lost Time] (Berlin, 2009) and Bruno Latour: Zur Einführung [Bruno Latour: An Introduction] (Hamburg, 2011). 